\title{
FORMULASI DAN AKTIVITAS ANTIBAKTERI KRIM ANTI ACNE EKSTRAK ETANOL BAWANG DAYAK (Eleutherine bulbosa (Mill.) Urb.) TERHADAP Staphylococcus epidermidis
}

\section{Formulation and Antibacterial Activity of Anti-acne Cream of Bawang Dayak Ethanol Extract (Eleutherine bulbosa (Mill.) Urb.) Against Staphylococcus epidermidis}

\author{
Syahrida Dian Ardhany ${ }^{*}$ \\ Sastri Septia' \\ Susi Novaryatiin' \\ *IProdi Farmasi Fakultas IImu \\ Kesehatan Universitas \\ Muhammadiyah Palangkaraya, \\ Palangka Raya, Kalimantan \\ Tengah, Indonesia \\ *email: chass50I@gmail.com
}

\begin{abstract}
Abstrak
Bawang Dayak merupakan salah satu tumbuhan khas Kalimantan yang berkhasiat sebagai obat tradisional. Secara empiris umbi Bawang Dayak dikenal memiliki khasiat untuk penyakit kulit seperti jerawat. Penelitian ini bertujuan untuk mengetahui perbedaan sifat fisik dari krim ekstrak etanol umbi Bawang Dayak pada hari ke-0 dan hari ke-7, serta untuk mengetahui aktivitas antibakterinya terhadap bakteri S. epidermidis dengan metode Disc Diffusion (kirby-bauer). Formulasi krim dibuat dalam berbagai variasi konsentrasi ekstrak etanol Bawang Dayak, FI (5\%), F2 (I0\%), F3 (I5\%), dan F4 (20\%). Hasil penelitian menunjukkan bahwa krim FI pada hari ke-0 memenuhi semua syarat uji homogenitas, $\mathrm{pH}$, daya lekat, dan daya sebar. Selanjutnya, semua formulasi krim anti acne ekstrak etanol umbi Bawang Dayak memiliki kemampuan menghambat bakteri Staphylococcus epidermidis pada FI (5\%), F2 (I0\%), F3 (15\%), dan F4 (20\%) dengan diameter zona hambat secara berturut-

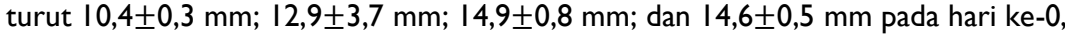
dan zona hambat berturut-turut $12,9 \pm 1,5 \mathrm{~mm} ; 16,9 \pm 1,0 \mathrm{~mm} ; 19,3 \pm 1,0 \mathrm{~mm}$; dan 20,3 \pm I, $4 \mathrm{~mm}$ pada hari ke-7 yang berarti terjadinya peningkatan daya hambat pada hari ke-7. Penelitian ini menunjukkan potensi krim ekstrak etanol umbi Bawang Dayak sebagai anti acne, namun perlu penelitian lebih lanjut untuk meningkatkan komposisi dan stabilitas formulasi sehingga dapat dikembangkan sebagai produk krim anti acne.
\end{abstract}

\begin{abstract}
Kata Kunci:
Jerawat

Bawang dayak

Krim

Eleutherine bulbosa

Tanaman obat

Abstract

Bawang Dayak is one of the typical plants of Borneo which is efficacious as traditional medicine. Empirically Bawang Dayak knows to have properties for skin diseases such as acne. This study aimed to determine the differences in the physical properties of anti-acne cream of Bawang Dayak (Eleutherine bulbosa (Mill.) Urb.) bulb ethanol extract on day 0 and day 7, and to determine its antibacterial activity against Staphylococcus epidermidis with Disc Diffusion (Kirby-Bauer) method. Cream formulation was made with various concentrations of Bawang Dayak ethanol extract, FI (5\%), F2 (I0\%), F3 (I5\%) and F4 (20\%). The results showed that $F I$ cream on day 0 fulfilled all the requirements for homogeneity, $\mathrm{pH}$, adhesion and dispersive ability. Furthermore, all anti-acne cream formulation of Bawang Dayak bulb ethanol extract had the ability to inhibit the Staphylococcus epidermidis in FI (5\%), F2 (I0\%), F3 (I5\%), and F4 (20\%) with inhibition zones were $10.4 \pm 0.3 \mathrm{~mm} ; 12.9 \pm 3.7 \mathrm{~mm} ; 14.9 \pm 0.8 \mathrm{~mm}$; and $14.6 \pm 0.5 \mathrm{~mm}$ on day 0 ; and inhibition zones were $12.9 \pm 1.5 \mathrm{~mm} ; 16.9 \pm 1.0 \mathrm{~mm} ; 19.3 \pm 1.0 \mathrm{~mm}$; dan $20.3 \pm 1.4$ $\mathrm{mm}$ on day 7 , which means there is an increase in inhibitory power on day 7. This study shows the potential of the ethanol extract of Bawang Dayak bulb as an anti-acne cream, but further research is needed to improve the composition and stability of the formulation so that it can be developed as an anti-acne cream product.

Keywords:

Bawang dayak

Cream

Eleutherine bulbosa

Medicinal plant
\end{abstract}

(C) year The Authors. Published by Institute for Research and Community Services Universitas Muhammadiyah Palangkaraya. This is Open Access article under the CC-BY-SA License (http://creativecommons.org/licenses/by-sa/4.0/). DOI: https://doi.org/10.33084/jsm.vxix.xxx.

\section{PENDAHULUAN}

Jerawat (acne vulgaris) adalah penyakit kulit yang menyerang pilosebasea kulit, yaitu kelenjar sebasea dan folikel rambut (Tan et al., 2018). Jerawat ditandai dengan perkembangan papula sebasea, jerawat kistik, lesi inflamasi, dan keterlibatan saluran folikel serta 
produksi sebum oleh bakteri Propionibacterium acnes, Staphylococcus epidermidis, dan Staphylococcus aureus (Shinde et al., 202I). P. acnes terlibat dalam perkembangan inflamasi jerawat dengan mengaktifkan komplemen dan metabolisme trigliserida sebasea menjadi asam lemak yang mengiritasi dinding folikel dan dermis sekitarnya (Vora et al., 2018; Zaenglein et al., 2016). S. epidermidis biasanya terlibat dalam infeksi superifisal di dalam unit sebasea, sedangkan pertumbuhan S. aureus dapat menyebabkan lesi jerawat (Shinde et al., 202I).

Salah satu tumbuhan khas Kalimantan yang berkhasiat sebagai obat tradisional adalah Bawang Dayak. Secara empiris umbi Bawang Dayak dikenal memiliki khasiat untuk mengatasi penyakit kulit seperti jerawat (Syamsul et al., 2015). Cara penggunaannya yaitu dengan menempelkan parutan umbi Bawang Dayak pada daerah yang luka atau diminum air rebusannya.

Berdasarkan penelitian sebelumnya diketahui bahwa ekstrak etanol umbi Bawang Dayak memiliki aktivitas antibakteri terhadap tiga bakteri penyebab jerawat yaitu Propionibacterium acnes, Staphylococcus epidermidis, dan Staphylococcus aureus (Novaryatiin \& Ardhany, 2019; Novaryatiin et al., 2019; Novaryatiin et al., 2018;). Selanjutnya ekstrak etanol umbi Bawang Dayak dibuat menjadi sediaan krim untuk meningkatkan efisiensi penggunaannya sebagai anti acne dan telah dilakukan uji fisik sediaan krim pada hari ke-0 dan hari ke-7, lalu diujikan aktivitas antibakterinya terhadap bakteri $P$. acnes. Hasil uji homogenitas pada hari ke-7 terpisah dan tidak homogen ( $F 3$ dan F4), namun $\mathrm{pH}$ semua formulasi cocok untuk aplikasi secara topikal. Pada hari ke-0, FI dan F2 menunjukkan aktivitas antibakteri dengan kategori weak activity, F3 dan F4 dalam kategori moderate activity. Sedangkan pada hari ke-7 semua formulasi memiliki aktivitas antibakteri dalam kategori weak activity (Ardhany et al., 2019; Ardhany \& Novaryatiin, 2019).

Penelitian ini bertujuan untuk mengetahui perbedaan sifat fisik dari krim ekstrak etanol umbi Bawang Dayak pada hari ke-0 dan yang disimpan hingga hari ke-7, serta untuk mengetahui aktivitas antibakterinya terhadap bakteri S. epidermidis. Dalam penelitian ini, formulasi krim dari penelitian sebelumnya sedikit dimodifikasi dengan penambahan jumlah oleum rosae bertujuan untuk meningkatkan sifat organoleptiknya, terutama untuk menyamarkan aroma Bawang Dayak.

\section{METODOLOGI}

\section{Alat dan Bahan}

Alat-alat yang digunakan pada penelitian ini adalah beaker glass, gelas ukur, tabung reaksi, erlenmeyer, labu ukur, pipet ukur, batang pengaduk, cawan porselin, cawan petri, mortar, stamper, bunsen, pinset, ballpipet, rak tabung reaksi, tabung reaksi, perkolator, waterbath, neraca analitik, blender, rotary evaporator, ose, kapas, lidi kapas steril, jangka sorong, Laminar Air Flow (LAF), autoklaf, inkubator, aluminium foil, glass pearl, kaca arloji, kertas label, dan korek api.

Bahan-bahan yang digunakan pada penelitian yaitu formulasi sediaan krim ekstrak etanol umbi Bawang Dayak (Eleutherine bulbosa (Mill.) Urb.), bakteri Staphylococcus epidermidis ATCC 12228, disc kosong, etanol 96\%, media Brain Heart Infusion (BHI), media Blood Agar Plate (BAP), media Mueller Hinton Agar (MHA), aquadest, $\mathrm{NaCl} 0,9 \%, \mathrm{H}_{2} \mathrm{SO}_{4} \mathrm{l} \%, \mathrm{BaCl} 1 \%$, asam stearate, trietanolamin, adeps lanae, paraffin cair, nipagin, oleum rosae, Standar McFarland 0,5, dan antibiotik Clindamycin.

\section{Metode}

Pemilihan dan Pengambilan Simplisia

Bawang Dayak (Eleutherine bulbosa (Mill.) Urb.) yang digunakan adalah umbi bawang Dayak yang dibudidaya di jalan Cendrawasih 2 UPT KM. 38, Kelurahan Sei Gohong, Kecamatan Bukit Batu, Kota Palangka Raya, Provinsi Kalimantan Tengah. 


\section{Pembuatan Simplisia}

Dilakukan sortasi basah pada umbi bawang Dayak, lalu dipotong-potong dan dijemur. Setelah kering simplisia disortasi kembali dan dihaluskan hingga menjadi serbuk (Depkes RI, 1995).

\section{Pembuatan Ekstrak}

Pembuatan ekstrak etanol umbi bawang Dayak dilakukan dengan metode perkolasi. Penggunaan pelarut etanol $96 \%$ karena etanol merupakan pelarut universal yang mampu melarutkan hampir seluruh jenis metabolit sekunder, tidak bersifat racun, serta aman untuk digunakan (Arifianti et al., 20l4). Ekstrak yang diperoleh lalu dibuat dalam berbagai variasi formulasi yaitu FI (5\%), F2 (I0\%), F3 (I5\%), dan F4 (20\%).

\section{Pembuatan Krim}

Bahan-bahan fase minyak (asam stearate, adeps lanae, paraffin cair) dan fase air (trietanolamin, nipagin, aquadest) dipisahkan, lalu masing-masing fase dipanaskan hingga melebur pada suhu $55^{\circ} \mathrm{C}$. Kemudian memasukkan fase minyak yang telah dilebur di atas waterbath ke dalam mortar, gerus cepat kemudian masukkan sedikit demi sedikit fase air, gerus sampai homogen hingga terbentuk basis krim, terakhir masukkan ekstrak bawang Dayak sedikit demi sedikit digerus hingga homogen, dan tambahkan pewangi oleum rosae, aduk sampai homogen (Nazliniwaty et al., 2016).

Tabel I. Formulasi krim ekstrak etanol umbi bawang dayak

\begin{tabular}{ccccc}
\hline \multirow{2}{*}{ Bahan } & \multicolumn{4}{c}{ Jumlah (mg) } \\
\cline { 2 - 5 } & $\mathbf{F I}$ & $\mathbf{F 2}$ & $\mathbf{F 3}$ & $\mathbf{F 4}$ \\
\hline $\begin{array}{c}\text { Ekstrak } \\
\text { etanol umbi } \\
\text { bawang dayak }\end{array}$ & $\begin{array}{c}1.250 \\
(5 \%)\end{array}$ & $\begin{array}{c}2.500 \\
(10 \%)\end{array}$ & $\begin{array}{c}3.750 \\
(15 \%)\end{array}$ & $\begin{array}{c}5.000 \\
(20 \%)\end{array}$ \\
\hline Asam stearat & 5.000 & 5.000 & 5.000 & 5.000 \\
\hline Adeps lanae & 750 & 750 & 750 & 750 \\
\hline Paraffin cair & 6.250 & 6.250 & 6.250 & 6.250 \\
\hline Trietanolamin & 375 & 375 & 375 & 375 \\
\hline Nipagin & 25 & 25 & 25 & 25 \\
\hline Oleum rosae & 15 tetes & 15 tetes & 15 tetes & 15 tetes \\
\hline Aquadest ad & 25.000 & 25.000 & 25.000 & 25.000 \\
\hline
\end{tabular}

Uji Evaluasi Krim

\section{Uji organoleptis}

Pemeriksaan yang dilakukan meliputi warna, aroma, dan tekstur yang diamati secara visual.

2. Uji homogenitas

Pemeriksaan terhadap homogenitas yang diamati secara visual. Sediaan krim diamati pada kaca objek untuk menemukan partikel kasar. Sediaan harus menunjukkan komposisi yang homogen dan tidak ada butiran kasar yang terlihat (Ardhany \& Novaryatiin, 2019).

3. Uji $\mathrm{pH}$

Krim dioleskan pada $\mathrm{pH}$ stik universal dan dibiarkan sampai menunjukkan nilai yang konstan, kemudian dibandingkan hasilnya dengan standar warna yang terdapat pada kemasan, selanjutnya dicatat pH krim (Syamsul et al., 2015).

4. Uji daya lekat

0,5 g sediaan diletakkan di atas gelas objek lalu diletakkan gelas objek yang lain di atas krim tersebut. Kemudian ditekan dengan beban I kg (5 menit). Pasang gelas objek pada alat uji. Pasang gelas objek pada alat uji. Pasang beban $80 \mathrm{~g}$ dan catat waktunya hingga kedua gelas objek terlepas (Safitri, 2016).

5. Uji daya sebar

$0,5 \mathrm{~g}$ sediaan diletakkan di tengah kaca bulat. $\mathrm{Di}$ atas krim diletakkan kaca bulat lain (I menit) kemudian dicatat diameter penyebarannya (Safitri, 2016).

6. Uji tipe krim

I g krim dioleskan pada telapak tangan, kemudian dicuci dengan sejumlah volume air sambal membilas tangan. Air dilewatkan dari buret dengan perlahan, amati secara visual ada atau tidaknya krim yang tersisa pada telapak tangan, dicatat volume air yang terpakai (Syamsul et al., 20I5). 


\section{Penanaman Bakteri Staphylococcus epidermidis}

Bakteri Staphylococcus epidermidis ditanam pada media $\mathrm{BHI}$ pada suhu $37^{\circ} \mathrm{C}$ selama 24 jam, lalu ditumbuhkan pada media BAP pada suhu $37{ }^{\circ} \mathrm{C}$ selama 24 jam (Novaryatiin et al., 2019).

\section{Uji Aktivitas Antibakteri}

Uji aktivitas antibakteri dilakukan menggunakan metode difusi disk (Kirby-Bauer). Setelah dibuat suspensi bakteri Staphylococcus epidermis yang disesuaikan dengan standar kekeruhan McFarland 0,5. Selanjutnya mengambil bakteri Staphylococcus epidermidis dari suspensi bakteri kemudian streak di media MHA dengan menggunakan kapas lidi steril. Kemudian merendam disc kosong pada kontrol positif dengan konsentrasi $0,5 \%, 1 \%, 2 \%$, dan $4 \%$, dan mengoleskan disc kosong pada masing-masing formulasi. Selanjutnya tanam disc Clindamycin dan formulasi sediaan krim sesuai dengan masing-masing konsentrasi yang sudah ditentukan pada media MHA. Menginkubasi pada suhu $37{ }^{\circ} \mathrm{C}$ selama 24 jam (Novaryatiin et al., 2019). Pengamatan dilakukan dengan cara mengukur diameter dari daya hambat yang terbentuk di sekitar disc menggunakan jangka sorong sebagai diameter zona hambat formulasi sediaan krim ekstrak etanol umbi Bawang Dayak pada hari ke-0 dan ke-7 terhadap pertumbuhan bakteri Staphylococcus epidermidis.

\section{HASIL DAN PEMBAHASAN}

\section{Rendemen Ekstrak}

Dari 5,3 kg umbi Bawang Dayak yang diekstraksi dengan metode perkolasi dengan pelarut etanol $96 \%$ dihasilkan 315,6 g ekstrak kental. Adapun rendemen ekstrak yang diperoleh sebesar $5,95 \%$.

\section{Hasil Uji Evaluasi Krim}

\section{Uji organoleptis}

Hasil uji organoleptis pada hari ke-0 menunjukkan bahwa keempat formulasi memiliki warna coklat muda, aroma khas Bawang Dayak, dan tekstur semi-solid (Tabel II). Berdasarkan pengamatan pada hari ke-7 penyimpanan, F3 dan F4 menunjukkan adanya perubahan warna yaitu menjadi coklat tua, serta semua formulasi memiliki bau yang menyengat dibandingkan pada hari ke-0 (Tabel III). Perbedaan warna disebabkan karena adanya perbedaan konsentrasi ekstrak etanol Bawang Dayak pada masing-masing formulasi krim. Selain itu, penambahan jumlah oleum rosae dalam formulasi krim pada penelitian kali ini masih belum dapat menyamarkan aroma menyengat Bawang Dayak.

Tabel II. Hasil pengamatan uji organoleptis hari ke-0

\begin{tabular}{|c|c|c|c|}
\hline Formulasi & Warna & Aroma & Tekstur \\
\hline $\mathrm{FI}$ & $\begin{array}{l}\text { Coklat } \\
\text { muda }\end{array}$ & $\begin{array}{c}\text { Khas bawang } \\
\text { dayak }\end{array}$ & Semi-solid \\
\hline F2 & $\begin{array}{l}\text { Coklat } \\
\text { muda }\end{array}$ & $\begin{array}{c}\text { Khas bawang } \\
\text { dayak }\end{array}$ & Semi-solid \\
\hline F3 & $\begin{array}{l}\text { Coklat } \\
\text { muda }\end{array}$ & $\begin{array}{c}\text { Khas bawang } \\
\text { dayak }\end{array}$ & Semi-solid \\
\hline F4 & $\begin{array}{l}\text { Coklat } \\
\text { muda }\end{array}$ & $\begin{array}{c}\text { Khas bawang } \\
\text { dayak }\end{array}$ & Semi-solid \\
\hline
\end{tabular}

Tabel III. Hasil pengamatan uji organoleptis hari ke-7

\begin{tabular}{|c|c|c|c|}
\hline Formulasi & Warna & Aroma & Tekstur \\
\hline $\mathrm{FI}$ & $\begin{array}{l}\text { Coklat } \\
\text { muda }\end{array}$ & $\begin{array}{c}\text { Khas bawang } \\
\text { dayak }\end{array}$ & Semi-solid \\
\hline F2 & $\begin{array}{l}\text { Coklat } \\
\text { muda }\end{array}$ & $\begin{array}{c}\text { Khas bawang } \\
\text { dayak }\end{array}$ & Semi-solid \\
\hline F3 & Coklat tua & $\begin{array}{c}\text { Khas bawang } \\
\text { dayak }\end{array}$ & Semi-solid \\
\hline F4 & Coklat tua & $\begin{array}{c}\text { Khas bawang } \\
\text { dayak }\end{array}$ & Semi-solid \\
\hline
\end{tabular}

2. Uji homogenitas

Hasil dari uji homogenitas pada hari ke-0 yaitu semua formulasi homogen (Tabel IV). Hasil uji pada hari ke-7 yaitu FI dan F2 tetap homogen, sedangkan F3 dan F4 terlihat tidak homogen dan cairan minyak yang memisah serta terdapat seperti adanya gumpalan (butiran kasar) (Tabel V). Hal ini disebabkan karena fase minyak lebih banyak dibandingkan dengan fase air sehingga tidak tercampur merata dan tidak membentuk massa krim yang baik. 
Tabel IV. Hasil pengamatan uji homogenitas hari ke-0

\begin{tabular}{ccc}
\hline Formulasi & Karakteristik & Homogenitas \\
\hline FI & Tidak ada butiran kasar & Homogen \\
\hline F2 & Tidak ada butiran kasar & Homogen \\
\hline F3 & Tidak ada butiran kasar & Homogen \\
\hline F4 & Tidak ada butiran kasar & Homogen \\
\hline
\end{tabular}

Tabel V. Hasil pengamatan uji homogenitas hari ke-7

\begin{tabular}{ccc}
\hline Formulasi & Karakteristik & Homogenitas \\
\hline FI & Tidak ada butiran kasar & Homogen \\
\hline F2 & Tidak ada butiran kasar & Homogen \\
\hline F3 & Ada butiran kasar & Tidak homogen \\
\hline F4 & Ada butiran kasar & Tidak homogen \\
\hline
\end{tabular}

\section{3. $U \mathrm{ji} \mathrm{pH}$}

Pengukuran $\mathrm{pH}$ krim dilakukan untuk mengetahui apakah krim memiliki $\mathrm{pH}$ yang sesuai dengan $\mathrm{pH}$ kulit sehingga tidak terlampau asam atau basa agar tidak merusak kulit (Anief, 20I0). Hasil pengukuran $\mathrm{pH}$ yang diperoleh pada hari ke-0 yaitu 6. Sedangkan pada hari ke-7, pH FI yaitu 5,6 dan $\mathrm{pH}$ formulasi lainnya adalah 6 (Tabel VI). Rentang nilai $\mathrm{pH}$ yang didapat dianggap masuk ke dalam persyaratan $\mathrm{pH}$ kulit yaitu antara 4,5-6,5 (Ernawati et al., 2017).

Tabel VI. Hasil uji pH hari ke-0 dan ke-7

\begin{tabular}{ccc}
\hline \multirow{2}{*}{ Formulasi } & \multicolumn{2}{c}{$\mathbf{p H}($ rata-rata \pm SD) } \\
\cline { 2 - 3 } & Hari ke-0 & Hari ke-7 \\
\hline FI & $6 \pm 0$ & $5,6 \pm 0,5$ \\
\hline F2 & $6 \pm 0$ & $6 \pm 0$ \\
\hline F3 & $6 \pm 0$ & $6 \pm 0$ \\
F4 & $6 \pm 0$ & $6 \pm 0$ \\
\hline
\end{tabular}

4. Uji daya lekat

Uji daya lekat bertujuan untuk mengetahui seberapa lama waktu perekatan krim pada permukaan kulit. Semakin lama krim melekat di kulit, maka semakin banyak zat aktif yang diserap. Sebuah krim memenuhi persyaratan jika memiliki daya lekat lebih dari 4 detik (Ulaen et al., 20I2). Hasil uji daya lekat pada penelitian ini menunjukkan bahwa pada hari ke-0 semua formulasi memenuhi syarat, sedangkan pada hari ke-7 semua formulasi tidak memenuhi syarat karena masih kurang dari 4 detik (Tabel VII).

Tabel VII. Hasil uji daya lekat hari ke-0 dan ke-7

\begin{tabular}{ccc}
\hline \multirow{2}{*}{ Formulasi } & Waktu (rata-rata \pm SD) (detik) \\
\cline { 2 - 3 } & Hari ke-0 & Hari ke-7 \\
\hline FI & $4,24 \pm 0,2$ & $2,17 \pm I, 3$ \\
F2 & $4,67 \pm 0,5$ & $2,76 \pm 0,9$ \\
\hline F3 & $4,85 \pm 0,6$ & $2,93 \pm 0,8$ \\
\hline F4 & $4,55 \pm 0,4$ & $2,43 \pm 0,6$ \\
\hline
\end{tabular}

5. Uji daya sebar

Uji daya sebar bertujuan untuk mengetahui kelunakan massa krim sehingga dapat dilihat kemudahan pengolesan sediaan ke kulit. Daya sebar dikatakan memenuhi syarat yaitu pada rentang 5-7 $\mathrm{cm}$ dengan adanya perlakuan penambahan beban (Rachmalia et al., 2016). Berdasarkan hasil penelitian yang diperoleh baik pada hari ke-0 maupun hari ke-7, FI dan F3 memenuhi syarat, sedangkan F2 dan F4 tidak memenuhi syarat karena daya sebar kurang dari $5 \mathrm{~cm}$ (Tabel VIII).

Tabel VIII. Hasil uji daya sebar hari ke-0 dan ke-7

\begin{tabular}{ccc}
\hline \multirow{2}{*}{ Formulasi } & \multicolumn{2}{c}{ Daya sebar (rata-rata \pm SD) $(\mathbf{c m})$} \\
\cline { 2 - 3 } & Hari ke-0 & Hari ke-7 \\
\hline FI & $6,19 \pm 0,5$ & $5,40 \pm 1,2$ \\
\hline F2 & $4,06 \pm 0,5$ & $4,92 \pm 0,9$ \\
\hline F3 & $5,4 \pm 0,9$ & $5,15 \pm 0,8$ \\
\hline F4 & $4,93 \pm 0,7$ & $4,37 \pm 1,3$ \\
\hline
\end{tabular}

6. Uji tipe krim

Pengujian tipe krim dilakukan karena pada umumnya untuk tujuan kosmetik tipe yang lebih cocok untuk krim yakni bertipe M/A salah satunya karena mudah tercuci air sehingga mudah digunakan (Fatmawati et al., 2020). Dapat dilihat pada Tabel IX, hasil uji tipe krim yang diperoleh pada keempat formulasi yaitu M/A. Hal ini disebabkan karena volume fase terdispersi (fase minyak) yang digunakan dalam sediaan krim lebih kecil dari fase pendispersi (fase air), sehingga fase 
minyak akan terdispersi ke dalam fase air membentuk emulsi tipe minyak dalam air (M/A) (Pratasik et al., 2019).

Tabel IX. Hasil uji tipe krim

\begin{tabular}{ccc}
\hline Formulasi & $\begin{array}{c}\text { Volume (rata-rata } \pm \mathbf{S D}) \\
(\mathbf{m L})\end{array}$ & Keterangan \\
\hline $\mathrm{FI}$ & $\mathrm{II}, 4 \pm 2,6$ & $\mathrm{M} / \mathrm{A}$ \\
\hline $\mathrm{F} 2$ & $\mathrm{II}, 0 \pm \mathrm{I}, 9$ & $\mathrm{M} / \mathrm{A}$ \\
\hline $\mathrm{F} 3$ & $10,7 \pm \mathrm{I}, 6$ & $\mathrm{M} / \mathrm{A}$ \\
\hline $\mathrm{F} 4$ & $10,5 \pm 0,9$ & $\mathrm{M} / \mathrm{A}$
\end{tabular}

\section{Hasil Uji Aktivitas Antibakteri}

Penelitian ini menggunakan kontrol positif yang berguna sebagai pembanding atau tolak ukur dalam menentukan kemampuan variasi formulasi ekstrak etanol umbi Bawang Dayak dalam menghambat bakteri. Clindamycin mempunyai mekanisme kerja yaitu membunuh bakteri dengan cara mencegah sintesis protein dari bakteri. Clindamycin merupakan antimikroba yang bersifat bakteriostatik maupun bakterisida (Putra et al., 20I7).

Konsentrasi Clindamycin yang digunakan adalah 0,5\%. 1\%. $2 \%$ dan $4 \%$ sehingga diperoleh zona hambat berturut-turut yaitu $37,6 \pm \mathrm{I}, 3 \mathrm{~mm} ; 39,4 \pm 0,5 \mathrm{~mm}$; $40,9 \pm 2,5 \mathrm{~mm}$; dan 44,6 $\pm 0,4 \mathrm{~mm}$. Aktivitas antibakteri dapat dibagi menjadi 3 tingkatan: weak activity (zona hambat kurang dari $12 \mathrm{~mm}$ ), moderate activity (zona hambat antara 12 dan $20 \mathrm{~mm}$ ), dan strong activity (zona hambat lebih dari $20 \mathrm{~mm}$ ) (Syahbazi, 2017). Jika dibandingkan dengan interpretasi daya hambat menurut Syahbazi (2017), maka keempat konsentrasi kontrol positif tersebut dapat dikategorikan sebagai strong activity (Tabel X).

Tabel X. Hasil pengukuran zona hambat dari kontrol positif

\begin{tabular}{ccc}
\hline $\begin{array}{c}\text { Konsentrasi } \\
\mathbf{( \% )}\end{array}$ & $\begin{array}{c}\text { Rata-rata zona } \\
\text { hambat } \pm \text { SD } \mathbf{( m m )}\end{array}$ & $\begin{array}{c}\text { Interpretasi } \\
\text { daya hambat } \\
\text { (Syahbazi, } \\
\mathbf{2 0} \mathbf{~ 7 )}\end{array}$ \\
\hline 0,5 & $37,6 \pm 1,3$ & Strong activity \\
\hline I & $39,4 \pm 0,5$ & Strong activity \\
\hline 2 & $40,9 \pm 2,5$ & Strong activity \\
\hline
\end{tabular}

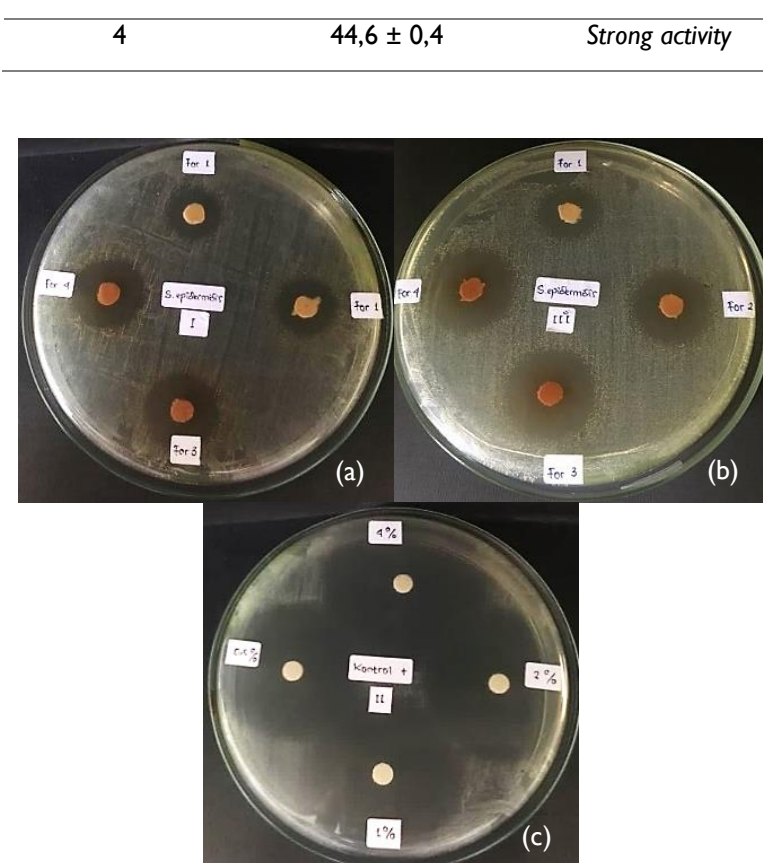

Gambar I. Aktivitas antibakteri formulasi krim anti acne ekstrak etanol umbi bawang dayak pada hari ke-0 (a), hari ke-7 (b), dan kontrol positif (c) terhadap bakteri S. epidermidis

Uji aktivitas antibakteri formulasi sediaan krim ekstrak etanol umbi Bawang Dayak dilakukan sebanyak 3 kali pengulangan, hasilnya seperti yang terlihat pada Gambar I. Hasil uji menunjukkan adanya zona hambat yang bervariasi. Rata-rata hasil pengukuran zona hambat formulasi sediaan krim ekstrak etanol umbi Bawang Dayak di hari ke-0 pada FI yaitu 10,4 $\pm 0,3 \mathrm{~mm}$ (weak activity), sedangkan pada F2, F3, dan F4 secara berturut-turut sebesar $12,9 \pm 3,7 \mathrm{~mm}$; 14,9 $\pm 0,8 \mathrm{~mm}$; dan 14,6 $\pm 0,5 \mathrm{~mm}$, yang jika diinterpretasikan ketiga formulasi tersebut masuk ke dalam kategori moderate activity (Tabel XI).

Tabel XI. Hasil pengukuran zona hambat formulasi krim anti acne ekstrak etanol umbi bawang dayak pada hari ke-0

\begin{tabular}{ccc}
\hline Formulasi & $\begin{array}{c}\text { Rata-rata zona } \\
\text { hambat } \pm \text { SD } \mathbf{( m m )}\end{array}$ & $\begin{array}{c}\text { Interpretasi daya } \\
\text { hambat } \\
\text { (Syahbazi, 20 I 7) }\end{array}$ \\
\hline FI & $10,4 \pm 0,3$ & Weak activity \\
\hline F2 & $12,9 \pm 3,7$ & Moderate activity \\
\hline F3 & $14,9 \pm 0,8$ & Moderate activity \\
\hline F4 & $14,6 \pm 0,5$ & Moderate activity \\
\hline
\end{tabular}


Tabel XII. Hasil pengukuran zona hambat formulasi krim anti acne ekstrak etanol umbi bawang dayak pada hari ke-7

\begin{tabular}{ccc}
\hline Formulasi & $\begin{array}{c}\text { Rata-rata zona } \\
\text { hambat } \pm \text { SD }(\mathbf{m m})\end{array}$ & $\begin{array}{c}\text { Interpretasi } \\
\text { daya hambat } \\
\text { (Syahbazi, } \\
\mathbf{2 0 I 7 )}\end{array}$ \\
\hline FI & $12,9 \pm 1,5$ & Moderate activity \\
\hline F2 & $16,9 \pm 1,0$ & Moderate activity \\
\hline F3 & $19,3 \pm 1,0$ & Moderate activity \\
\hline F4 & $20,3 \pm 1,4$ & Strong activity \\
\hline
\end{tabular}

Rata-rata hasil pengukuran zona hambat formulasi sediaan krim ekstrak etanol umbi Bawang Dayak di hari ke-7 pada FI, F2, F3, dan F4 berturut-turut $12,9 \pm \mathrm{I}, 5 \mathrm{~mm} ; 16,9 \pm \mathrm{I}, 0 \mathrm{~mm} ; 19,3 \pm \mathrm{I}, 0 \mathrm{~mm}$; dan 20,3 $\pm \mathrm{I}, 4 \mathrm{~mm}$. Jika dibandingkan dengan interpretasi daya hambat menurut Syahbazi (20I7), maka FI, F2, dan F3 dikategorikan moderate activity, Sedangkan F4 dikategorikan strong activity (Tabel XII). Pada hari ke-7 hasil yang diperoleh semakin tinggi konsentrasi dari ekstrak etanol umbi Bawang Dayak maka semakin besar daya hambatnya (Dewi \& Mardhiyani, 202I). Kemampuan menghasilkan zona bening (hambat) diduga bergantung pada metabolit sekunder yang dimiliki sampel (Ouchari et al., 2019). Hal ini sejalan dengan penelitian sebelumnya yang menemukan adanya kandungan senyawa flavonoid, alkaloid, saponin dan tanin dalam ekstrak etanol umbi Bawang Dayak (Novaryatiin \& Ardhany, 2019), yang dapat bertanggungjawab terhadap sifat antibakteri yang diamati. Keempat senyawa kimi tersebut diketahui memiliki kemampuan sebagai antibakteri. Flavonoid dapat menghambat sintesis dinding sel bakteri (Pratama et al., 20I8), alkaloid bekerja melalui aktivitas penghambatan pompa efluks (Thawabteh et al., 2019). Saponin dapat menyebabkan kebocoran isi dinding sel bakteri (Dong et al., 2020), dan tanin diketahui memiliki sifat antibakteri terhadap bakteri Gramnegatif dan Gram-positif (Kurhekar, 2016; Maisetta et al., 2019).

\section{KESIMPULAN}

Berdasarkan hasil penelitian yang telah dilakukan, maka dapat disimpulkan bahwa krim FI pada hari ke-0 memenuhi semua syarat uji homogenitas, $\mathrm{pH}$, daya lekat, dan daya sebar. Selanjutnya, semua formulasi krim anti acne ekstrak etanol umbi Bawang Dayak mampu menghambat pertumbuhan bakteri Staphylococcus epidermidis pada FI (5\%), F2 (I0\%), F3 (I5\%), dan F4 (20\%) dengan diameter zona hambat secara berturut-turut 10,4 $\pm 0,3 \mathrm{~mm} ; 12,9 \pm 3,7 \mathrm{~mm}$;

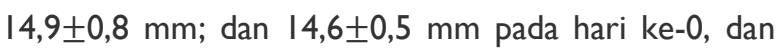
zona hambat berturut-turut $12,9 \pm 1,5 \mathrm{~mm} ; 16,9 \pm 1,0$

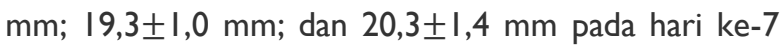
yang berarti terjadinya peningkatan daya hambat pada hari ke-7. Penelitian ini menunjukkan potensi krim ekstrak etanol umbi Bawang Dayak sebagai anti acne, namun perlu penelitian lebih lanjut untuk meningkatkan komposisi dan stabilitas formulasi sehingga dapat dikembangkan sebagai produk krim anti acne.

\section{UCAPAN TERIMA KASIH}

Berisi Informasi ucapan terima kasih serta penghargaan kepada pihak-pihak yang telah berpartisipasi dalam kegiatan penelitian yang dilakukan. Bisa kepada institusi penyedia anggaran maupun hibah (mencantumkan sumber dan skema hibah yang digunakan), pihak institusi tempat kegiatan penelitian dilakukan, narasumber, organisasi dan unsur masyarakat, serta sivitas akademika yang telah membantu pelaksanaan kegiatan penelitian.

\section{REFERENSI}

I. Tan, A.U., Schlosser, B.J., \& Paller, A.S. 2018 A Review of Diagnosis and Treatment of Acne in Adult Female Patients. International Journal of Women's Dermatology. 4:567I.doi:10.1016/j.ijwd.2017.10.006

2. Shinde, P., Sapate, R., Shinde, S., Kadam, A., Jadhav, R., Mali, H., \& Gidde, N. 2021. Formulation and Optimization of Semi Herbal Anti Acne Compact Face 
Powder by Allium Sativum and Myristica Fragrans Extract. Indo American Journal of Pharmaceutical Research. I (4): I642-I649. doi:I 0.528I/zenodo.4772489

3. Vora, J., Srivastava, A., \& Modi, H. 2018. Antibacterial and Antioxidant Strategies for Acne Treatment Through Plant Extracts. Informatics in Medicine Unlocked. 13:128-132. doi:10.1016/j.imu.2017.10.005

4. Zaenglein, A.L., Pathy, A.L., Schlosser, B.J., Alikhan, A., Baldwin, H.E., Berson, D.S., et al. 2016. Guideline of Care for The Management of Acne Vulgaris. Journal of American Academy of Dermatology. 74(5):945-973.e33. doi:I0.10I6/j.jaad.20I5.12.037

5. Syamsul, E.K., Supomo, Wijaya, H., \& Nugroho, B.A. 2015. Formulasi Ekstrak Etanol Umbi Bawang Tiwai (Eleutherine americana) dalam Sediaan Krim Anti Acne. Tradisional Medical Journal. 20(3).

6. Novaryatiin, S., \& Ardhany, S.D. 2019. The Antibacterial Activity of Bawang Dayak (Eleutherine bulbosa (Mill.) Urb.) from Central Kalimantan Against Acne-Causing Bacteria. Internationa Journal of Applied Pharmaceutics. I I (SI5):22-25. doi:I0.22 I59/ijap.2019.v| |s5.T0032

7. Novaryatiin, S., Ramli, A., \& Ardhany, S.D. 2019. Uji Daya Hambat Ekstrak Etanol Bawang Dayak (Eleutherine bulbosa (Mill.) Urb.) Terhadap Bakteri Staphylococcus aureus. Iurnal Surya Medika. 4(2):5 I-59. doi: I0.33084/jsm.v4i2.565

8. Novaryatiin, S., Pratiwi, A.M. \& Ardhany, S.D. 2018. Uji Daya Hambat Ekstrak Etanol Bawang Dayak (Eleutherine bulbosa (Mill.) Urb.) Terhadap Bakteri Staphylococcus epidermidis. Anterior jurnal. I8(I):92-97. doi: 10.33084/anterior.v| 8il.392

9. Ardhany, S.D., Puspitasari, Y., Meydawati, Y., \& Novaryatiin, S. 2019. Formulasi Sediaan Krim Anti Acne dan Uji Aktivitas Ekstrak Etanol Bawang Dayak (Eleutherine bulbpsa (Mill.) Urb.) Terhadap Propionibacterium acnes. Jurnal Sains dan Kesehatan. 20(2):121-126. doi: 10.25026/jsk.v2i2.136

10. Ardhany, S.D., \& Novaryatiin, S. 2019. Antibacterial Activity of Ethanolic Extract Bawang Dayak (Eleutherine bulbosa (Mill.) Urb.) in Cream Against Propionibacterium acnes. Int I App Pharm. I I (SI5): I -4. doi: I 0.22 I59/ijap.20 I9.v I I s5.T0020

II. Departemen Kesehatan Republik Indonesia. 1995. Materia Medika Indonesia. Jilid VI. Jakarta.
12. Arifianti, L. Oktarina, R.D., \& Kusumawati, I. 2014. Pengaruh Jenis Pelarut Pengekstraksi Terhadap Kadar Sinensetin dalam Ekstrak Daun Orthosiphon stamineus Benth. E-Journal Planta Husada. 2(I): I-4.

13. Nazliniwaty, Arianto, A., \& Nasution, K.R.A. 2016. Formulation and Anti-Aging Effect of Cream Containing Breadfruit (Artocarpus altilis (Parkinson) Fosberg) Leaf Extract. International Journal of PharmTech Research. 9(12):524-530.

14. Safitri, F.W., Syahreza, A., Farah, H.S., Satrio, B.M., \& Hadi, S.I. 2016. Antioxidant Activities and Antioxidant Cream Formulation of Corn Silk (Zea Mays L) Extract. Sains Medika. 7(2):64-69.

15. Anief, M. 2010. Ilmu Meracik Obat. Yogyakarta: Gajah Mada University Press.

16. Ermawati, D., Chasanah, U., \& Dwi, D. 2017. Optimization Formulation on Antioxidant Cream Vitamin E ( $\alpha$-Tocopherol Acetate) with Virgin Coconut Oil (VCO). Advances in Health Science (AHSR). 2:362-366.

I7. Ulaen, S.P.J., Banne, Y., \& Suatan, R.A. 2012. Pembuatan Salep Anti Jerawat dari Ekstrak Rimpang Temulawak (Curcuma xanthorrhiza Roxb). Jurnal Ilmiah Farmasi. 3(2):45-49.

18. Rachmalia, N., Mukhlishah, I., Sugihartini, N., \& Yuwono, T. 2016. Daya Iritasi dan Sifat Fisik Sediaan Salep Minyak Atsiri Bunga Cengkih (Syzigium aromaticum) pada Basis Hidrokarbon. Majalah Farmaseutik. 12: 372-376.

19. Fatmawati, F., Jafar, G., \& Riantini, R. 2020. Pengujian Penghambatan Enzim Tirosinase pada Formulasi Masker Pencerah Wajah dari Kombinasi Kefir Susu Sapi dan Rumput Laut (Euchema cottonii). Analit: Analytical and Environmental Chemistry. 5(I):42-52.

20. Putra, R.E.D., Homenta, H. \& Wowor, V.N.S. 2017. Uji Daya Hambat Perasan Jeruk Purut Citru hytrix Terhadap Bakteri Staphylococcus epidermidis in Vitro. Pharmacon. 6(I): 65-66.

21. Shahbazi, Y. 2017 Antibacterial and Antioxidant Properties of Methanolic Extracts of Apple (Malus pumila), Grape (Vitis vinifera), Pomegranate (Punica granatum L.), and Common Fig (Ficus carica L.) Fruits. Pharmaceutical Sciences. 24(4):308-315. doi:10.15I7I/PS.2017.45

22. Dewi, A.P., \& Mardhiyani, D. 2021. Formulation and Antibacterial Activity of Liquid Soap 
Containing Ketapang (Terminalia catappa L.) Leaves Extract. Borneo Journal of Pharmacy. 4(I):43-50. doi: 10.33084/bjop.v4il. 1589

23. Ouchari, L., Boukeskasse, A., Bouizgarne, B., \& Ouhdouch, Y. 2019. Antimicrobial Potential of Actinomycetes Isolated from The Unexplored Hot Merzouga Desert and Their Taxonomic Diversity. Biology Open. 8: I-7. doi:I0.1242/bio.035410

24. Pratama, M.R.F., \& Aziz, I.R. 2019. Molecular Docking of Bawang Dayak (Eleutherine bulbosa) Secondary Metabolites as Bacterial Cell Wall Synthesis Inhibitor. Proceedings of the $I^{\text {st }}$ International Conference on Science and Technology; 2019 May 2-3; Makassar, Indonesia. Ghent: EAl. doi:10.4I08/eai.2-52019.2284686

25. Thawabteh, A., Juma, S., Bader, M., Karaman, D., Scrano, L., Bufo, S.A., et al. 2019. The Biological Activity of Natural Alkaloids Against Herbivores, Cancerous Cells and Pathogens. Toxins (Basel). I I ( I I),656: I-28. doi: I 0.3390/toxins I I I I0656

26. Dong, S., Yang, X., Zhao, L., Zhang, F., Hou, Z., \& Xue, P. 2020. Antibacterial Activity and Mechanism of Action Saponins from Chenopodium quinoa Willd. Husks Against Foodborne Pathogenic Bacteria. Industrial Crops and Products. 149:I-I4. doi: I0.1016/j.indcrop.2020.II2350

27. Kurhekar, J.V. 2016. Tannins-Antimicrobial Chemical Components. International Journal of Technology and Science. 9(3):5-9.

28. Maisetta, G., Batoni, G., Caboni, P., Esin, S., Rinaldi, A.C., \& Zucca, P. 2019. Tannin Profile, Antioxidant Properties, and Antimicrobial Activity of Extracts from Two Mediterranean Species of Parasitic Plant Cytinus. BMC Complementary and Alternative Medicine. 19(82): I-I I. doi: I0.I I86/s | 2906-019-2487-7

29. Pratasik, M.C.M., Yamlean, P.V.Y., \& Wiyono, W.I. 2019. Formulasi dan Uji Stabilitas Fisik Sediaan Krim Ekstrak Etanol Daun Sesewanua (Clerodendron squamatum Vahl.). Pharmacon. 8(2):26I-267. 